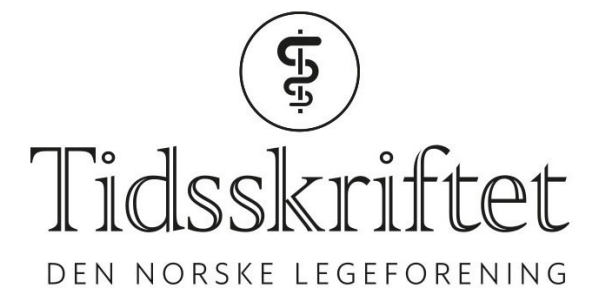

DEN NORSKE LEGEFORENING

\title{
Medisinstudiet gir ikke fremtidige leger nødvendig teknologisk kompetanse
}

DEBATT

\section{HÅVARD ULSAKER}

Håvard Ulsaker (f. 1997) er medisinstudent ved Norges teknisk-naturvitenskapelige universitet, og han er grunnutdanningsansvarlig for 2018 i Norsk medisinstudentforening. Forfatter har fylt ut ICMJE-skjemaet og oppgir ingen interessekonflikter.

Dagens medisinstudenter skal være yrkesaktive frem til 2060-70. Det er sannsynlig at fremskrittene som kommer i løpet av vår karriere, vil stille enda større krav til teknisk kompetanse enn tidligere. I hvilken grad forbereder medisinstudiet oss på å arbeide med teknologiske løsninger i morgendagens helsevesen?

Teknologiske nyvinninger vil komme i alle sektorer av arbeidslivet, og helsesektoren er intet unntak. Det er vi nødt til å forholde oss til.

Kunstig intelligens kommer trolig til å spille en vesentlig rolle i fremtidens pasientbehandling. IBMs «Dr. Watson» er bare startskuddet. Watson er en superdatamaskin som kan foreslå behandling basert på pasientens anamnese, ved å integrere enorme informasjonsmengder fra en rekke ulike kilder (1). Maskinen er langt unna å være en fullgod behandler (2), men teknologien kan være en pekepinn på hva vi har i vente.

Med god tilrettelegging kan vi se for oss en omfattende database hvor samtlige radiologibilder og patologiske snitt er samlet, noe som kan brukes til opplæring av maskiner i tradisjonell radiologi og patologi. «Dette er malignt melanom, dette her er noe annet», «dette er prostatacancer, dette er ikke det», kan vi fortelle maskinen. Med tilstrekkelig opplæring, basert på presis informasjon og datagrunnlag av høy kvalitet, kan maskinen regelrett laere seg selv å gjenkjenne mønstre i bilder den aldri har sett før. Med tilgang til millionvis på millionvis av gigabyte med data er potensialet til kunstig intelligens, for eksempel innen radiologi og patologi, trolig enormt (3).

Roboter kan komme til å spille en viktig rolle i morgendagens kirurgi. I dag betjenes det aller meste av robotkirurgi av leger. Det er ikke gitt at det vil være tilfellet om 30 år. Da har kanskje robotene så stor prosessorkraft at de, ved hjelp av neste generasjons bildeassistanse, kan finne frem i kroppen på egen hånd og skjære ut en svulst med mye større presisjon enn vi har mulighet til i dag (4). Menneskelige vurderinger vil trolig ikke kunne erstattes på lang tid, men jeg tenker at det er viktig å være klar over at automatisering av kirurgi kan gi høyere kvalitet, bredere tilgang og lavere kostnader.

Kommende leger må forholde seg til pasienter som kommer med store mengder 
helseinformasjon fra mer eller mindre kompetente helseapper. Vil

selvmonitoreringsverktøy være et verdifullt tilskudd i en travel fastlegehverdag eller vil det føre med seg for mye informasjon?

\section{Legene må med}

Utviklingen av et mer digitalisert og høyteknologisk helsevesen stiller krav til teknisk kompetanse hos helsepersonellet. Vår oppgave bør være å diskutere og vurdere i hvilken grad nye løsninger vil føre til bedre pasientbehandling. Det må vi gjøre på et informert og forskningsbasert grunnlag med en god porsjon sunn skepsis. Gir dagens utdanning oss et grunnlag for å vurdere nytten av ny teknologi? Jeg mener nei.

I høst deltok jeg på konferansen E-helse i Norge (EHiN), hvor forskjellige aktører innen ehelseindustrien kommer for å vise frem sine produkter. Det som overrasket meg mest med konferansen, var i hvor liten grad leger og annet helsepersonell er med på utformingen av løsningene som ble presentert. Det er synd. Behovet for helsepersonell i innovasjon diskuteres av medisinstudenter og leger andre steder, blant annet i USA (5). Det er vi som står i de daglige utfordringene og ser hvilke behov pasientene våre har. Leger har mange tanker om hva som kan forbedres, og vet å påpeke det. Det er et paradoks at ideer og frustrasjon sjeldent omsettes til handlinger. Grunnen kan være at vi mangler nødvendig kunnskap om teknologi og innovasjon.

\section{Endringer i utdanningen}

Jeg har to ønsker for endringer i medisinutdanningen: For det første burde medisinstudiet gi bedre muligheter for å tilegne seg relevant teknologisk kunnskap, i hvert fall for studenter med interesse for slikt. Slik kunnskap bør meritteres på lik linje med at forskningskompetanse anerkjennes gjennom forskerlinjen.

For det andre burde grunnutdanningen i større grad stimulere fremtidige leger til å drive med medisinsk innovasjon og delta i utviklingen av fremtidens løsninger. Utdanningen bør synliggjøre hvilke muligheter leger har til å jobbe med entreprenørskap og innovativ forskning og anerkjenne at andre enn helseforetakene og primærhelsetjenesten kan være potensielle arbeidsgivere.

Teknologien kommer. Vi må være med på utviklingen - eller ta konsekvensene av en teknologirevolusjon vi valgte ikke å være med på.

LITTERATUR:

1. Watson Health IBM. 2017. Watson HealthIBM. https://www.ibm.com/watson/health/ (21.11.2017).

2. Ross C, Swetlitz I. IBM pitched its Watson supercomputer as a revolution in cancer care. It's nowhere close. https://www.statnews.com/2017/09/05/watson-ibm-cancer/ (21.11.2017).

3. Jha S, Topol EJ. Adapting to artificial intelligence: radiologists and pathologists as information specialists. JAMA 2016; 316: 2353 - 4. [PubMed][CrossRef]

4. Shademan A, Decker RS, Opfermann JD et al. Supervised autonomous robotic soft tissue surgery. Sci Transl Med 2016; 8: 337ra64. [PubMed][CrossRef]

5. Chakma J. Science-savvy physicians. Science 2009;325:1204 - 5. [PubMed][CrossRef]

Publisert: 8. januar 2018. Tidsskr Nor Legeforen. DOI: 10.4045/tidsskr.17.0991

Mottatt 13.11.2017, første revisjon innsendt 21.11.2017, godkjent 28.11.2017.

(C) Tidsskrift for Den norske legeforening 2020. Lastet ned fra tidsskriftet.no 